Article

\title{
Antidiarrheal Activity of 19-Deoxyicetexone Isolated from Salvia ballotiflora Benth in Mice and Rats
}

\author{
Salud Pérez-Gutiérrez ${ }^{1}$, Daniel Zavala-Mendoza ${ }^{2}$, Abigail Hernández-Munive ${ }^{1}$, \\ Ángel Mendoza-Martínez ${ }^{3}$, Cuauhtemoc Pérez-González ${ }^{1}$ and Ernesto Sánchez-Mendoza ${ }^{1 *}$ \\ 1 Departamento de Sistemas Biológicos, Universidad Autónoma Metropolitana. Unidad Xochimilco, \\ Calzada del Hueso 1100, Col. Villa Quietud, Coyoacán 04960, Mexico \\ 2 Doctorado en Biología Experimental. D.C.B.S. Universidad Autónoma Metropolitana. \\ Unidad Iztapalapa, Av. San Rafael Atlixco No. 186 Col. Vicentina, Iztapalapa 09340, Mexico \\ 3 Centro de Química, ICUAP, Benemérita Universidad Autónoma de Puebla, \\ Ciudad Universitaria Puebla 72592, Mexico \\ * Author to whom correspondence should be addressed; E-Mail: esanchez@correo.xoc.uam.mx; \\ Tel.: +52-55-5483-7263; Fax: +52-55-5483-7410.
}

Received: 16 June 2013; in revised form: 17 July 2013 / Accepted: 23 July 2013 /

Published: 26 July 2013

\begin{abstract}
The antidiarrheal properties of 19-deoxyicetexone, a diterpenoid isolated from Salvia ballotiflora were evaluated on castor oil-, arachidonic acid (AA)- and prostaglandin $\left(\mathrm{PGE}_{2}\right)$-induced diarrhea in rodent models. The structure of 19-deoxyicetexone was determined by X-ray crystallography, mass spectrometry (EI-MS), as well as ultraviolet (UV-Vis), infrared (FT-IR) and nuclear magnetic resonance (NMR) spectroscopies. This compound significantly and dose-dependently reduced frequency of stooling in castor oil-induced diarrhea, and at dose of $25 \mathrm{mg} / \mathrm{kg}$ it also inhibited diarrhea induced with AA, while it had no effect on $\mathrm{PGE}_{2}$-induced diarrhea. This compound at doses of $25 \mathrm{mg} / \mathrm{kg}$ also diminished castor oil-induced enteropooling and intestinal motility, and inhibited the contraction of the rats' ileum induced by carbachol chloride at a concentration of $100 \mu \mathrm{g} / \mathrm{mL}$. 19-Deoxyicetexone did not present acute toxicity at doses of $625 \mathrm{mg} / \mathrm{kg}$. Its antidiarrheal activity may be due to increased reabsorption of $\mathrm{NaCl}$ and water and inhibition of the release of prostaglandins, gastrointestinal motility and fluid accumulation in the intestinal tracts of rats. These findings suggest that 19-deoxyicetexone may be used in the treatment of diarrhea, although more studies must be carried out to confirm this.
\end{abstract}


Keywords: Salvia ballotiflora; antidiarrheal activity; 19-deoxyicetexone

\section{Introduction}

Diarrheal disease is one of the main causes of the high mortality rate in developing countries, particularly among children under the age of five [1]. Diarrhea is most common in crowded living conditions coupled with poor hygiene and malnutrition [2]. Thus, it is important to identify and evaluate natural drugs that can be used as alternatives to commonly used antidiarrheal drugs, which are often accompanied by adverse effects such as addiction and constipation [3]. Consequently, much research is now being devoted to the discovery of new antidiarrheal compounds isolated from natural products. In some cases, these compounds may be more specific and less toxic than those obtained by synthesis. Numerous plants from all continents have traditionally been used in the treatment of diarrheal disease [4].

According to World Health Organization (WHO) about $80 \%$ of the World's population depends mainly on traditional medicine and the use of plant extracts are involved in these traditional treatments [5], mainly due to the economic viability, accessibility and ancestral experience [6]. In particular, Mexico has great environmental and biological diversity and is home to a wide range of medicinal plants with antidiarrheal properties have been used by traditional healers. However, the effectiveness of many of these plants has not been scientifically evaluated, and the compounds responsible for the antidiarrheal effects of these plants have not been characterized in most cases.

Salvia ballotiflora Benth (Acanthaceae) is commonly known in Mexican traditional medicine as mejorana and is a multi-branched aromatic shrub with square stems. The leaves of the plant contain serrated margins and have hairs on the top and bottom. The flowers of the plant are bluish-purple in color and grow in elongated clusters. This plant has been used by the indigenous people of Mexico to relieve postpartum symptoms [7].

In 1997, Esquivel et al [8] isolated three icetexane diterpenoids from the aerial parts of Salvia ballotiflora, and their chemical structures were elucidated using spectroscopic methods. These compounds were identified as 19-deoxyicetexone, 19-deoxyisoicetexone and 7,20-dihydroanastomosine.

The aim of the present study was to obtain and conform the identity of the diterpenoid 19-deoxyicetexone isolated from Salvia ballotiflora and evaluate for the first time its antidiarrheal properties in castor oil-, arachidonic acid (AA)- and prostaglandin ( $\mathrm{PGE}_{2}$ )-induced rodent diarrhea models as well as its effects on intestinal transit and castor oil-induced enteropooling.

\section{Results and Discussion}

\subsection{Structural Analyses}

The chemical structure of 19-deoxyicetexone was unequivocally determined using X-ray crystallography (Figure 1a) by making use of the anomalous scattering of $\mathrm{Cu} \mathrm{K}_{\alpha}$ radiation with the Flack parameter being refined to 0.09 (19). The absolute configuration of compound revealed three chiral centers: $\mathrm{C} 8=\mathrm{S}, \mathrm{C} 10=\mathrm{S}$, and $\mathrm{C} 11=\mathrm{S}$ (Figure $1 \mathrm{~b}$ ). 
The crystal structure of 19-deoxyicetexone was deposited at the Cambridge Crystallographic Data Centre (deposition number: CCDC 917975). Crystal data: $\mathrm{C}_{20} \mathrm{H}_{24} \mathrm{O}_{4}$, orange needles, $\mathrm{T}=293$ (2) $\mathrm{K}$, $\mathrm{Cu} K \alpha \lambda=1.54184 \AA$, crystal system orthorhombic, space group $P 22_{1} 2_{1} 2_{1}$, unit cell dimensions: $a=7.7141$ (1) $\AA, b=10.5176$ (2) $\AA$, and $c=20.7343$ (3) $\AA, \alpha=\beta=\gamma=90^{\circ}, V=1682.25(5) \AA^{3} . Z=4$, $D x=1.297 \mathrm{mg} \mathrm{m}^{-3}, \mu=0.72 \mathrm{~mm}^{-1}$, and $\mathrm{F}(000)=704$. Collected reflections: 12117 ; independent reflections: 3443 in a $\theta_{\max }=77.1^{\circ}$ and $\theta_{\min }=4.3^{\circ}(-6 \leq h \geq 9,-13 \leq k \geq 13,-26 \leq l \geq 25)$. Final $R$ indices (all data), $R 1=0.045$ and $w R 2=0.121$.

Figure 1. (a) Structure of 19-deoxyicetexone. (b) X-ray ORTEP diagram of 19-deoxyicetexone.
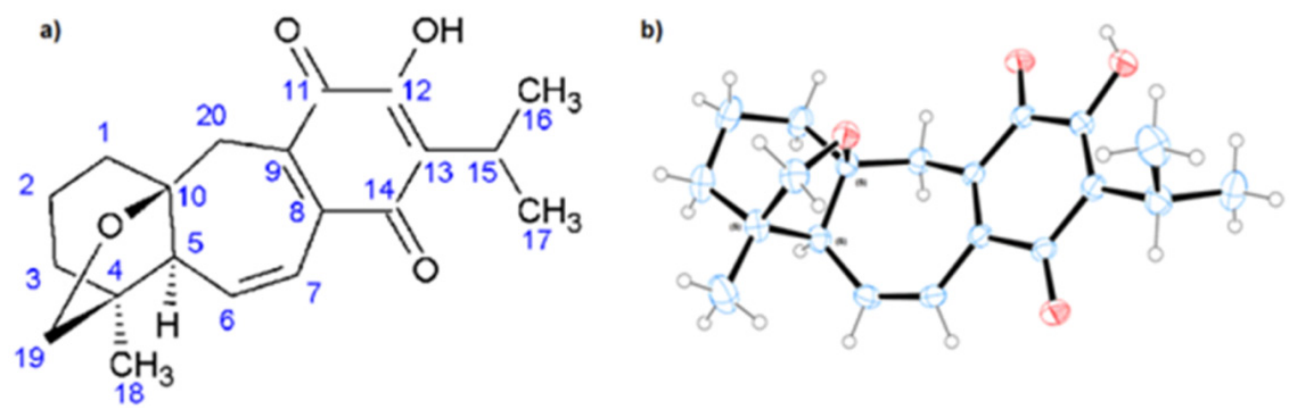

19-Deoxyicetexone was previously reported by Esquivel et al. [8]. Our ${ }^{13} \mathrm{C}-\mathrm{NMR}$, EI-MS and infrared data are consistent with the previously reported data. However, there were some discrepant results: the melting point in the present study was $203-204{ }^{\circ} \mathrm{C}$, the optical rotation $[\alpha]_{\mathrm{D}}=-66.81$, and the UV $\lambda_{\max }^{\mathrm{MeOH}} 264$ and $317 \mathrm{~nm}$ (as opposed to mp 228-230 ${ }^{\circ} \mathrm{C},[\alpha]^{20}=+95$ and the UV $\lambda_{\max }^{\mathrm{MeOH}} 211$, 290 , and $318 \mathrm{~nm}$ as previously reported). In addition, we add to the scientific record the complete ${ }^{1}$ H-NMR assignment of 19-deoxyicetexone (Table 1).

Table 1. NMR spectroscopy data for 19-deoxyicetexone (600 MHz. $\mathrm{CDCl}_{3}$ ).

\begin{tabular}{|c|c|c|c|c|c|}
\hline Position & $\delta^{13} \mathrm{C}(\mathrm{ppm})$ & $\delta^{1} \mathrm{H}(\mathrm{ppm})$ & Position & $\delta^{13} \mathrm{C}(\mathrm{ppm})$ & $\delta^{1} \mathbf{H}(\mathrm{ppm})$ \\
\hline 1 & $39.88(39.8) *$ & $1.76(\mathrm{~m}), 1.70(\mathrm{~m})$ & 12 & $150.75(150.7) *$ & - \\
\hline 2 & $20.19(20.2) *$ & $1.89(\mathrm{~m}), 1.68(\mathrm{~m})$ & 13 & $124.48(124.4) *$ & - \\
\hline 3 & $39.19(39.1) *$ & $1.57(\mathrm{~m}), 1.50(\mathrm{tdd})$ & 14 & $186.54(186.5) *$ & - \\
\hline 4 & $43.90(43.9) *$ & - & 15 & $24.30(24.3) *$ & 3.22 (hept) \\
\hline 5 & $59.30(59.3) *$ & $2.31 \mathrm{dd}$ & 16 & $19.92(19.9) *$ & $1.24(\mathrm{~d})$ \\
\hline 6 & $141.82(141.8) *$ & $6.51 \mathrm{dd}$ & 17 & $19.88(19.9) *$ & $1.23(\mathrm{~d})$ \\
\hline 7 & $124.13(124.1) *$ & $6.81 \mathrm{dd}$ & 18 & $20.03(19.5) *$ & $1.04(\mathrm{~s})$ \\
\hline 8 & $135.63(135.5) *$ & - & 19 & $77.72(77.6) *$ & $3.70(\mathrm{~d}), 3.50(\mathrm{dd})$ \\
\hline 9 & $139.95(138.6) *$ & - & 20 & $33.23(33.2) *$ & $2.98(\mathrm{~d}), 2.59(\mathrm{~d})$ \\
\hline 10 & $92.91(92.9) *$ & - & $\mathrm{OH}$ & - & $7.17(\mathrm{~s})$ \\
\hline 11 & $183.31(183.3) *$ & - & & & \\
\hline
\end{tabular}




\subsection{Pharmacological Study of 19-Deoxyicetexone}

\subsubsection{Acute Toxicity}

Oral administration of 19-deoxyicetexone at doses of 312.5 or $625 \mathrm{mg} / \mathrm{kg}$ produced no visible signs of toxicity (for example, restlessness and seizures) in the animals. No deaths were recorded following the administration of these two doses.

\subsubsection{Antidiarrheal Activity}

Thirty minutes after castor oil administration, diarrhea was clinically apparent in all animals of the group administered only with vehicle for the next $4 \mathrm{~h}$. Table 2 shows that loperamide administration at a dose of $2.5 \mathrm{mg} / \mathrm{kg}$ markedly reduced diarrhea $(81.5 \pm 4.5)$ when compared to the untreated rats. A similar reduction in the total number of defecations over a $4 \mathrm{~h}$, period was achieved with 19-deoxyicetexone at doses of 12.5 and $25 \mathrm{mg} / \mathrm{kg}$ (61.8 and $89.6 \%$, respectively). However, at doses of $6.25 \mathrm{mg} / \mathrm{kg}$ this compound did not affect the severity and onset diarrhea.

Table 2. The antidiarrheal effects of 19-deoxyicetexone on mice induced castor oil-induced diarrhea.

\begin{tabular}{ccc}
\hline Treatment & Doses $\mathbf{~ m g} / \mathbf{k g}$ & Percentage of inhibition \\
\hline Vehicle & $0.1 \mathrm{~mL}$ & 0.0 \\
\hline \multirow{3}{*}{ 19-Deoxyicetexone } & 6.25 & $30.9 \pm 7.2^{\mathrm{ns}}$ \\
\cline { 2 - 3 } & 12.5 & $61.8 \pm 5.5^{*}$ \\
\cline { 2 - 3 } & 25 & $89.6 \pm 1.7^{* *}$ \\
\hline Loperamide & 2.5 & $81.5 \pm 4.5^{* *}$ \\
\hline
\end{tabular}

The results are the means of 10 animals \pm standard error. ${ }^{*} p<0.05$ and $* * p<0.001$ with respect to the vehicle-treated group.

It is well known that castor oil produces diarrhea due to the most active metabolite ricinoleic acid which causes irritation and inflammation of the intestinal mucosa, leading to release of prostaglandins [9,10] and nitric oxide $[11,12]$ which stimulate the intestinal motility, secretion and diminish the reabsorption of $\mathrm{NaCl}$ and $\mathrm{H}_{2} \mathrm{O}[13,14]$. The results of the present study indicate that 19-deoxyicetexone produced a statistically significant reduction in the severity and frequency of castor oil-induced diarrhea.

For this reason the activity of 19-deoxyicetexone was tested on mice with AA- or PGE 2 -induced diarrhea. The inhibitory effect of the compound on AA-induced diarrhea at a dose of $25 \mathrm{mg} / \mathrm{kg}$ was $75.0 \pm 2.3 \%$, which was similar to that observed with loperamide at doses of $2.5 \mathrm{mg} / \mathrm{kg}(77.8 \pm 4.5 \%)$ (Table 3). 19-Deoxyicetexone produced a significant inhibition of AA-induced diarrhea but this compound had no effect on $\mathrm{PGE}_{2}$-induced diarrhea, suggesting that 19-deoxyicetexone inhibited the release of prostaglandins [15] and that this diterpenoid shows affinity and selectivity for the opioid receptor [16]. 
Table 3. The antidiarrheal effects of 19-deoxyicetexone on mice induced AA- or $\mathrm{PGE}_{2}$-induced diarrhea.

\begin{tabular}{lccc}
\hline Cathartic agent & Treatment & Doses mg/kg & Percentage of inhibition \\
\hline \multirow{3}{*}{ Arachidonic acid } & Vehicle & $0.1 \mathrm{~mL}$ & 0.0 \\
\cline { 2 - 4 } & 19-Deoxyicetexone & 25 & $75.0 \pm 2.3^{* *}$ \\
\cline { 2 - 4 } & Loperamide & 2.5 & $77.8 \pm 4.5^{* *}$ \\
\hline \multirow{3}{*}{ Prostaglandins $E_{2}$} & Vehicle & $0.1 \mathrm{~mL}$ & 0.0 \\
\cline { 2 - 4 } & 19-Deoxyicetexone & 25 & $22.2 \pm 9.1^{\mathrm{ns}}$ \\
\cline { 2 - 4 } & Loperamide & 2.5 & $69.4 \pm 2.3^{* *}$ \\
\hline
\end{tabular}

The results are the means of 10 animals \pm standard error. ${ }^{* *} p<0.001$ with respect to the vehicle-treated group.

\subsubsection{Ileum Contractions}

The contractile response obtained by stimulating a strip of the longitudinal layer of the Wistar rat ileum with carbachol chloride, which was applied at concentrations of $0.01,0.1,1.0,10$ and $100 \mu \mathrm{M}$ was evaluated (Figure 2). The peak amplitude of the successive carbachol-induced contractions declined when $100 \mu \mathrm{g} / \mathrm{mL}$ of 19-deoxyicetexone was added. This compound reduced the contractile force by almost $68 \%$, suggesting that 19 -deoxyicetexone is a competitive blocker of carbachol chloride and that this effect may be due to the interaction of 19-deoxyicetexone with the carbachol chloride muscarinic receptor $(\mu 3)[17,18]$.

Figure 2. Effect of 19-deoxyicetexone $(100 \mu \mathrm{g} / \mathrm{mL})$ on the contraction of ileum stimulated with carbachol chloride. The results are the mean of six determinations \pm standard error. ** $p<0.001$ with respect to the carbachol chloride-treated.

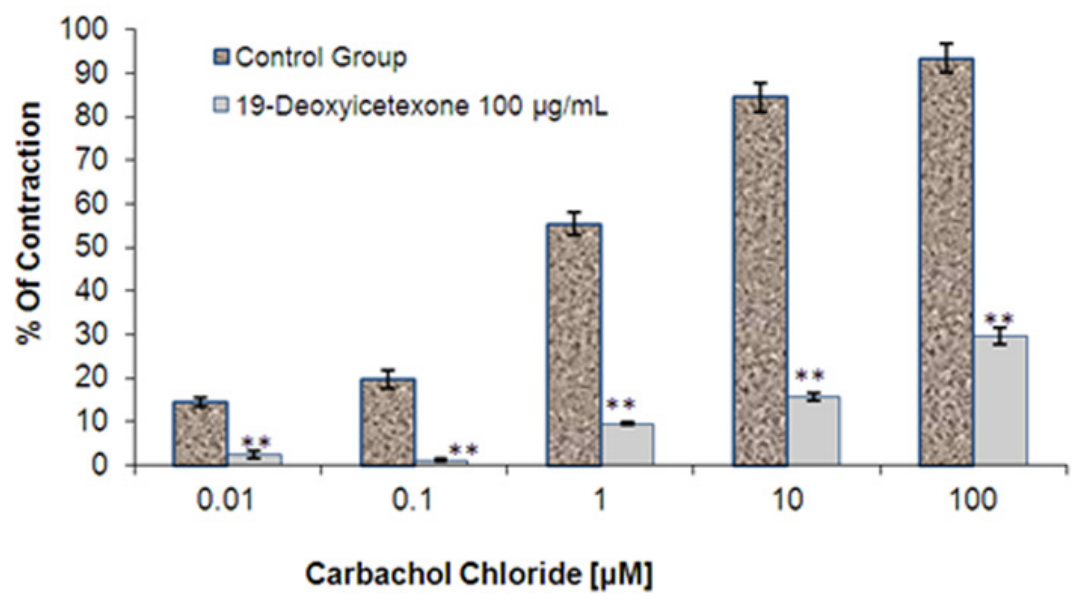

\subsubsection{Small Intestinal Transit}

The charcoal meal moved farther during castor oil-induced intestinal transit compared to normal intestinal transit. In the presence of castor oil, the percent of intestinal transit was increased (100\%) after $90 \mathrm{~min}$ (Figure 3), but was reduced in the presence of loperamide at dose of $2.5 \mathrm{mg} / \mathrm{kg}(61 \%)$ and 19-deoxyicetexone at dose of $25 \mathrm{mg} / \mathrm{kg}(60 \%)$. This result might be due to its anticholinergic effects [18]. 
Figure 3. Effects of 19-deoxyicetexone $(25 \mathrm{mg} / \mathrm{kg})$ on intestinal transit in rats. The results are the means of five determinations \pm standard error. ${ }^{*} p<0.05$ with respect to the castor oil-treated group.

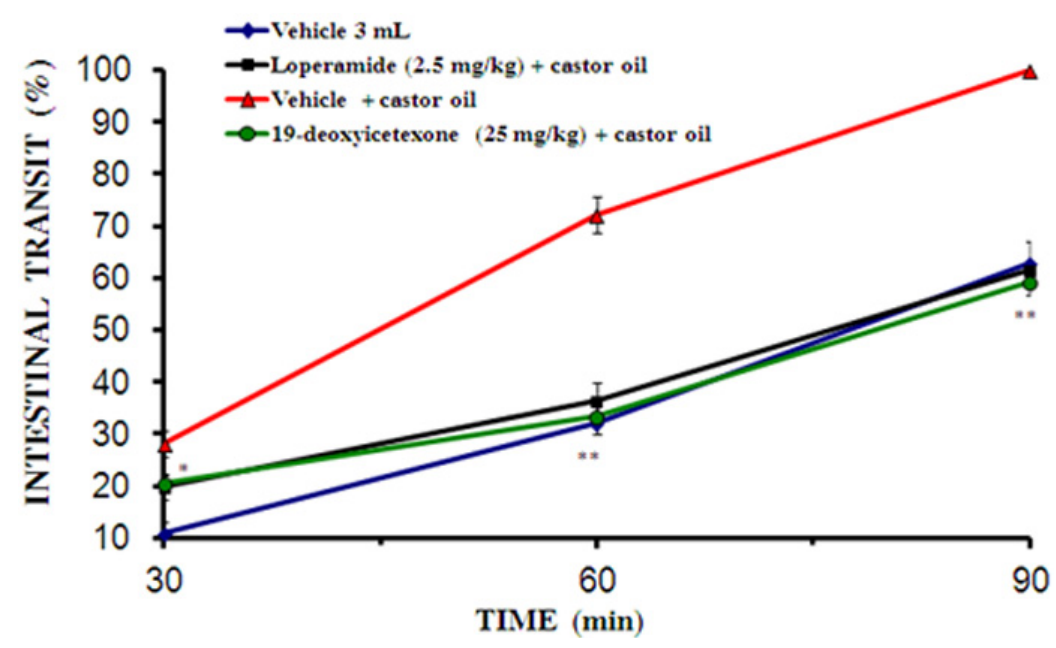

\subsubsection{Castor Oil-Induced Enteropooling}

Administration of castor oil resulted in the accumulation of water and electrolytes in the intestinal loop. 19-Deoxyicetexone $(25 \mathrm{mg} / \mathrm{kg})$ administration significantly inhibited castor oil-induced intestinal fluid accumulation in rats $(53.3 \%$ of weight) to a value that was similar to that obtained with loperamide (60\%) (Table 4).

Table 4. Effect of 19-deoxyicetexone on castor oil induced intestinal fluid accumulation.

\begin{tabular}{cccc}
\hline Treatment & Dose $(\mathbf{m g} / \mathbf{k g})$ & Wt of intestinal content (g) & \% Inhibition \\
\hline Control (vehicle) & $2 \mathrm{~mL}$ & $0.5 \pm 0.3$ & \\
Castor oil & $2 \mathrm{~mL}$ & $3.0 \pm 0.06$ & \\
19-Deoxyicetexone & 25 & $1.4 \pm 0.2 *$ & 53.3 \\
Loperamide & 2.5 & $1.2 \pm 0.3 *$ & 60.0 \\
\hline
\end{tabular}

The results are the mean of 10 animals \pm standard error; $* * p<0.005$ with respect to the castor oil-treated group.

Castor oil produced accumulation of water and electrolytes in the intestinal loop. 19-Deoxyicetexone inhibited castor oil-induced intestinal fluid accumulation in rats. The mechanism involved has been associated with the dual effects of gastrointestinal motility as well as water and electrolyte transport across the intestinal mucosa [19]. Thus, it is possible to suggest that 19-deoxyicetexone reduced diarrhea by increasing reabsorption of electrolytes and water or by inhibiting induced intestinal accumulation of fluid just like the standard drugs such as loperamide.

The results of this study indicate that 19-deoxyicetexone has antidiarrheal activity, and this might be due to its effect on reduction of water and electrolytes, inhibition release of $\mathrm{PGE}_{2}$ reduction number of gastrointestinal motility and fluid accumulation in the intestinal tract of rats, the acute toxicity is very low. No damage was observed on intestine, liver and kidney. Thus, this compound could potentially be used in the treatment of diarrhea. 


\section{Experimental}

\subsection{Plant Material}

Salvia ballotiflora was collected in Las Comadres Municipality of Guadalcazar, San Luis Potosi State, México in July of 2010. Vegetal identification was performed by taxonomist José García Pérez. A voucher specimen (SLPM 43013) was deposited at the herbarium Isidro Palacios Herbarium of the Universidad Autónoma de San Luis Potosí.

\subsection{Extraction and Isolation of 19-Deoxyicetexone}

The dried and ground plant (854 g) was extracted with $\mathrm{CHCl}_{3}(5 \mathrm{~L})$ at its boiling point for $4 \mathrm{~h}$. The solvent was removed under vacuum to yield $20.7 \mathrm{~g}$ of a gummy residue (2.42\%). Ten grams of this extract were fractionated in an open chromatographic column packed with silica gel 60 . Mixtures of hexane-ethyl acetate with increasing polarities were used for fractionation. The final solution used was $100 \%$ ethyl acetate. The fractionation process was monitored using thin layer chromatography. The isolated compound was obtained from fraction 8 (176 $\mathrm{mg})$. This compound was named 19-deoxyicetexone and is an orange crystalline solid with a melting point of $203-204{ }^{\circ} \mathrm{C}$ and an optical rotation of $[\alpha]^{20}=-66.81\left(\mathrm{c} 0.2, \mathrm{CHCl}_{3}\right)$.

\subsection{Structural Analysis of 19-Deoxyicetexone}

Structural identification was performed using X-ray crystallography, and UV-Vis, FT-IR, and NMR spectroscopies. The molecular weight was obtained by EI-MS. The crystallographic data were collected on an Oxford Gemini-Atlas diffractometer with $\mathrm{Cu} \mathrm{K} \mathrm{K}_{\alpha}$ radiation $(\lambda=1.54184 \AA)$ at 298 (2) $\mathrm{K}$. The mass spectrum was recorded using the Electronic Ionization (EI) method in the positive mode by direct injection on a Jeol-MStation mass spectrophotometer. The UV spectrum was obtained in a $\mathrm{CHCl}_{3}$ solution on a Shimadzu spectrophotometer double beam model UV-1800. The IR spectrum was recorded with an ATR accessory using a Perkin-Elmer Paragon 1000 FT-IR spectrophotometer. NMR spectra were recorded in a $\mathrm{CDCl}_{3}$ solution at $299 \mathrm{~K}$ on an Agilent DD2 600 spectrometer. The ${ }^{1} \mathrm{H}$ and ${ }^{13} \mathrm{C}$ NMR chemical shifts were reported relative to TMS and $\mathrm{CDCl}_{3}$, respectively.

\subsection{Antidiarrheal Activity}

\subsubsection{Animals}

Male CD1 mice (20-25 g) and male Wistar rats (200-250 g) were obtained from the Universidad Autónoma Metropolitana animal facility, and housed in isolated cages under standardized conditions (dark/light $12 / 12$ ) at $30{ }^{\circ} \mathrm{C}$ and $50 \%-55 \%$ humidity. They were supplied with Pet Food 5001 (LabDiet ${ }^{\circledR}$, Richmond, IN, USA) and water ad libitum. The animals were submitted to a fasting period of 18-24 h with free access to water prior the study. All the experiments were performed according to the international guidelines for the care of laboratory animals; they were sacrificed by cervical dislocation according to the international guidelines for the care of laboratory animals [20]. 


\subsubsection{Evaluation of Antidiarrheal Activity}

Groups of 10 mice were orally administered either the compound $(6.25,12.5$ or $25 \mathrm{mg} / \mathrm{kg}$ ), loperamide $(2.5 \mathrm{mg} / \mathrm{kg})$, or vehicle $(0.1 \mathrm{~mL}) 30 \mathrm{~min}$ prior to the oral administration of castor oil $(4 \mathrm{~mL} / \mathrm{kg})[21,22]$. Following castor oil treatment, the animals were placed separately in acrylic cages with filter paper at the bottom, which was changed every hour. The severity of diarrhea was assessed every hour for $4 \mathrm{~h}$. The total amount of watery feces excreted was scored and compared with the score obtained in the control group. The total diarrheic feces score from the control group was considered to be $100 \%$. The results are expressed as the percentage of inhibition.

\subsubsection{Evaluation of Antidiarrheal Activity in AA- and $\mathrm{PGE}_{2}$-Induced Diarrhea}

After evaluating the activity using the models described above, the effects of 19-deoxyicetexone at a dose of $25 \mathrm{mg} / \mathrm{kg}$ were evaluated on AA- $(3 \mathrm{mg} / \mathrm{kg})$ or $\mathrm{PGE}_{2^{-}}(1 \mathrm{mg} / \mathrm{kg})$ induced diarrhea in accordance with the methods described by Melo et al. [23].

\subsubsection{Evaluation of the Effects of 19-Deoxyicetexone on Ileum Contractions}

Male Wistar rats $(300 \mathrm{~g})$ were sacrificed by cervical dislocation according to the international guidelines for the care of laboratory animals [20]. The abdomens were opened and segments of the ileum (10 cm proximal to the caecum) were flushed twice with an aerated physiological salt solution (PSS) to remove their contents. The ileum segments were cut into smaller segments $(1 \mathrm{~cm}$ long approximately), which were placed in a $2 \mathrm{~mL}$ organ bath containing PSS with the following composition (mM): $\mathrm{NaCl}$ (118), $\mathrm{NaHCO}_{3}$ (25), $\mathrm{KCl}$ (4.7), $\mathrm{KH}_{2} \mathrm{PO}_{4}$ (1.2), $\mathrm{MgSO}_{4}$ (1.2), $\mathrm{CaCl}_{2}$ (2.5) and D-glucose (11). The organ bath was maintained at $36{ }^{\circ} \mathrm{C}$ while being aerated by bubbling with a mixture of $95 \% \mathrm{O}_{2}$ and $5 \% \mathrm{CO}_{2}(\mathrm{pH} 7.4)$. The ileum contractions were recorded isometrically with a Grass FT03 force displacement transducer connected to a Grass TBRS2 polygraph. The tissues were allowed to equilibrate for $60 \mathrm{~min}$, during which time the PSS was changed every $20 \mathrm{~min}$ and maintained under an optimal tension of $1 \mathrm{~g}$ prior to the initiation of experiment. After equilibration, the ileum rings were bathed in a depolarization solution $(23 \mathrm{mM} \mathrm{KCl})$ that was prepared by equimolecular substitution of $\mathrm{NaCl}$ for $\mathrm{KCl}$ to expose the tissues to a single sub-maximal concentration of $\mathrm{KCl}$ $(23 \mathrm{mM})$ and elicit contractile activity. Control contractile responses were considered to be two successive similar responses.

A group of tissues $(n=6)$ were incubated 10 min with solvent (ethanol-dimethyl sulfoxide 1:1, $20 \mu \mathrm{L}$ ) corresponding to $1 \%$ in the bath. Each group of tissues was stimulated with a different concentration of carbachol chloride $(0.01,0.1,1.0,10$ and $100 \mu \mathrm{M})$, the amplitude was measured. After that, each tissue was incubated with 19-deoxyicetexone $(100 \mu \mathrm{g} / \mathrm{mL})$ and then was added above concentrations of carbachol chloride and the amplitude was recorded according to the model described by Estrada et al. [24]. The contractile response for each tissue treated with carbachol chloride was considered to be a response of $100 \%$ and was compared with the contractile response of the tissues that had been pretreated with 19-deoxyicetexone. 


\subsubsection{Small Intestinal Transit}

Small intestinal transit was evaluated according to the method described by Visher et al. [25]. A $2.0 \%$ suspension of graphite in $1.5 \%$ agar was administered orally to groups of 15 rats $(1.5 \mathrm{~mL} / \mathrm{animal})$. The inhibitory action of the extracts on stimulated intestinal transit was tested using the following procedure: Castor oil $(4 \mathrm{~mL} / \mathrm{kg}$ ) was administered along with a graphite-agar suspension $60 \mathrm{~min}$ after the vehicle or the extract had been administered. At 30,60 and 90 min after the administration of the graphite-agar suspension plus castor oil, the rats were killed in groups of five and the gastrointestinal tracts were removed and opened. Distance traveled by the marker was measured and expressed as a percentage of the total length of the intestine from pylorus to caecum.

\subsubsection{Castor Oil-Induced Enteropooling}

Intraluminal fluid accumulation was evaluated according to the method described by Robert et al. [26]. Overnight fasted rats were divided in groups of six animals each, they were administered orally. Group 1 received vehicle $(1 \mathrm{~mL} / \mathrm{rat})$, group 2 received loperamide $(2.5 \mathrm{mg} / \mathrm{kg})$, and group 3 received 19-deoxyicetexone $(25 \mathrm{mg} / \mathrm{kg}) 1 \mathrm{~h}$ prior to the oral administration of castor oil $(2 \mathrm{~mL} / \mathrm{rat})$. Two hours later, the rats were sacrificed, the small intestines were removed after tying the ends, the intestinal contents were collected by milking into a graduated tube and their weights were measured.

\subsubsection{Acute Toxicity}

19-Deoxyicetexone was orally administered as a single dose to groups of mice $(n=5)$ at doses of 625 and $312 \mathrm{mg} / \mathrm{kg}$. The range of doses used in mice was based upon the OECD method [27]. After administration, the animals were observed under open-field conditions for a $72 \mathrm{~h}$ period. The number of animal deaths and all signs of clinical toxicity were recorded. Intestine, liver, and kidney were grossly examined.

\subsubsection{Statistical Analyses}

The results are expressed as the means \pm s.e.m. The mean values of intestinal transit were evaluated using Student's $t$-test, and the antidiarrheal activity, effect on inhibition of ileum contractile activity and castor oil-induced enteropooling were analyzed using ANOVA followed by Tukey's post-hoc test. The tests were used to compare the mean values of the activity of each group with the control group. The statistical significance was set at $p<0.05$.

\section{Conclusions}

The results of the present study suggest that 19-deoxyicetexone has antidiarrheal activity, which may be due to increased reabsorption of $\mathrm{NaCl}$ and water and inhibition of the release of prostaglandins, as well as inhibition of gastrointestinal motility and fluid accumulation in the intestinal tracts of rats and the mechanisms of this compound might involve inhibition of enteric neurotransmission, however, further studies must be carried out to verify this. Thus, this compound could potentially be used for the treatment of diarrhea. 


\section{Conflict of Interest}

The authors declare no conflict of interest.

\section{References}

1. World Health Organization. Water and Sanitation; WHO: Geneva, Switzerland, 1996; Volume 12.

2. Syder, J.D.; Merson, M.H. The magnitude of the global problems of acute diarrhoeal disease a review of active surveillance data. Bull. World Health Organ. 1982, 60, 605-613.

3. Hardman, J.G.; Limbird, L.E. Goodman and Gilman's: The Pharmacological Basis of Therapeutics; McGraw Hill: New York, NY, USA, 2010; pp. 914-931.

4. Kumar, S.; Garg, V.K.; Kumar, N.; Sharma, P.K.; Chaudhary, S.; Upadhyay, A. Pharmacognostical studies on the leaves of Ziziphus nummularia (Burm. F.). Eur. J. Exper. Biol. 2011, 1, 77-83.

5. Beverly, C.D.; Sudarsanam, G. Ethnomedicinal plant knowledge and practice of people of Javadhu hills in Tamilnadu. Asian Pac. J. Trop. Biomed. 2011, 1, S79-S81.

6. Wendel, G.H.; María, A.O.; Guzmán, J.A.; Giordano, O.; Pelzer, L.E. Antidiarrheal activity of dehydroleucodiene isolated from Artemisia douglasiana. Fitoterapia 2008, 79, 1-5.

7. Biblioteca digital de la Medicina Tradicional Mexicana. Available online: http://www.medicinatradicionalmexicana.unam.mx (accessed on 3 March 2013).

8. Esquivel, B.; Calderón, J.S.; Flores, E.; Sánchez, A.A.; Rosas, R. Abietane and icetexane diterpenoids from Salvia ballotaeflora and Salvia axillaris. Phytochemistry 1997, 46, 531-534.

9. Cappasso, F.; Mascolo, N.; Izzo, A.A.; Gaginella, T.S. Dissociation of castor oil-induced diarrhea and intestinal mucosal injury in rat: Effect of NG nitro-L-arginine methylester. Br. J. Pharm. 1994, 113, 1127-1130.

10. Capasso, F.; Tavares, I.A.; Bennet, A. PAF formation by human gastrointestinal mucosa/submucosa in vitro: Release by ricinoleic acid, and inhibition by 5 -aminosalicylic acid. J. Pharm. Pharmacol. 1992, 44, 771-772.

11. Mascolo, N.; Izzo, A.A.; Gaginella, T.S.; Capasso, F. Relationship between nitric oxide and platelet activating factor in castor oil-induced mucosal injury in the rat duodenum. Naunyn Schmiedebergs Arch. Pharmacol. 1996, 353, 680-684.

12. Uchida, M.; Yoshida, K.; Kato, Y.; Matsuede, K.; Shode, R.; Muraoka, A.; Yemato, S. Involvement of nitric oxide from nerves on diarrhea induced by castor oil in rats. Jpn. J. Pharmacol. 2000, 82, 168-170.

13. Galvez, J.; Zarzuelo, A.; Crespo, M.E.; Lorente, M.D.; Ocete, M.A.; Jimenez, J. Anti-diarrheic activity of Euphorbia hirta extract and isolation pf an active flavonoids constituents. Planta Medica 1993, 59, 333-336.

14. Edwards, R.; Smock, A.; Defective arachidonate release and $\mathrm{PGE}_{2}$ production in Gia2-deficient intestinal and colonic subepithelial myofibroblasts. Inflamm. Bowel Dis. 2006, 12, 153-155.

15. Venegas, R.; Pérez, S.; Ferrer, R.; Moreno, J.J. Arachidonic acid cascade and epithelial barrier function during Caco-2 cell differentiation. J. Lipid Res. 2006, 47, 1416-1423.

16. Bao, X.; Liu, D.; Jin, Y.; Yang, Y. A facile synthesis for novel loperamide analogs as potential $\mu$ opioid receptors agonists. Molecules 2012, 17, 14288-14297. 
17. Kojima, Y.; Tsunoda, Y.; Owyang, C.; Adenosine 39,59-cyclic monophosphate-stimulated Ca ${ }^{++}$ efflux and acetylcholine release in ileal myenteric plexus are mediated by $\mathrm{N}$-type $\mathrm{Ca}^{++}$channels: Inhibition by the kappa opioid receptor agonist. JPET 1997, 282, 403-409.

18. Dharmsathaphorn, K.; Cohn J.; Beuerlein, G. Multiple calcium-mediated effector mechanisms regulate chloride secretory responses in T84 cells. Am. J. Physiol. 1989, 256, C1224-C1230.

19. Gaginella, T.S.; Phillips, S.F. Ricinoleic acid: Current view of ancient oil. Am. J. Dig. Dis. 1975, 20, 1171-1177.

20. The International Guiding Principles for Biomedical Research Involving Animals. The Council for International Organizations of Medical Sciences (CIOMS) 1985. Available online: http://cioms.ch/publications/guidelines/1985_texts_of_guidelines.htm/ (accessed on 17 July 2013).

21. Awouters, F.; Niemegeers, C.J.S.; Lenaerts, F.M.; Jansen, P.A.J.J. Delay of castor oil diarrhoea in rats: A new way to evaluate inhibitors of Prostaglandin biosynthesis. J. Pharm. Pharmacol. 1978, $30,41-45$.

22. Zavala, M.A. Estudio Químico-Farmacológico de Plantas con Actividad Antidiarreica. Tesis doctoral, Universidad Autónoma Metropolitana, Unidad Xochimilco, Coyoacán Ciudad de México, México, 1998.

23. Melo, M.; Thomas, G.; Mukherjee, R. Antidiarrhoeal activity of bisnodihydrotoxiferine isolated from the root bark of Strychnos trinervis (Vell.) Mart. (Loganiaceae). J. Pharm. Pharmacol. 1988, 40, 79-82.

24. Estrada, S.; Gonzalez, D.; Castillo, P.; Aguirre, F.; Sánchez, J. Spasmolityc effect of Mentha pulegium L. involves ionic flux regulation in rat ileum strips. J. Smooth Muscle Res. 2010, 46, 107-117.

25. Vischer, P.; Casals-Stenzel, J. Influence of prostacyclin and indometacine on castor oil-induced gastrointestinal effects in rats. J. Pharm. Pharmacol. 1983, 35, 152-155.

26. Robert, A.; Nezamis, J.E.; Lancaster, C.; Hanchar, A.J.; Klepper, M.S. Enteropooling assay; a test for diarrhea produced by prostaglandins. Prostaglandins 1976, 11, 809-828.

27. OECD. Guideline for Testing of Chemicals. Acute Oral Toxicity-Fixed Dose Procedure 420; OECD: Paris, France, 2001.

Sample Availability: Samples of the compounds are available from the authors.

(C) 2013 by the authors; licensee MDPI, Basel, Switzerland. This article is an open access article distributed under the terms and conditions of the Creative Commons Attribution license (http://creativecommons.org/licenses/by/3.0/). 